\title{
IMPLEMENTASI PEMBERIAN REWARD DAN PUNISHMENT DALAM MEMBENTUK KARAKTER DISIPLIN ANAK USIA
}

\author{
Mila Sabartiningsih \\ Raudhatul Athfal An-Nawaa III Kota Cirebon \\ E-mail: milasabar@gmail.com \\ Jajang Aisyul Muzakki \\ IAIN Syekh Nurjati Cirebon \\ E-mail: jajangaisyulmuzakki@yahoo.co.id \\ Durtam \\ IAIN Syekh Nurjarti Cirebon \\ E-Mail: zisandurtam@gmail.com
}

Article received: 06 Februari 2018, Review process: 10 Maret 2018

Article published: 30 Maret 2018

\begin{abstract}
Discipline is one of the basic needs of children in the framework of the formation and development of his character in a healthy manner. The goal is for children to be creative and dynamic in developing their life in the future. Unconditional love leads to a sense of sentiment and carelessness, whereas discipline without affection is cruel tyranny. Parents and teachers always think of the right way to apply discipline discipline for children from toddlers to childhood and adolescence. This study aims to obtain data on the Implementation of Reward and Punishment In Character Building Discipline of Early Childhood In Group B in RA An-Nawaa 3 Cirebon City. In order in order to discipline early childhood especially in group B. teachers use several strategies including reward and punishment. Reward means reward, honor which is made as an educational tool and given when a child does a good or has managed to reach a certain stage of development. Kopri $(2015,289)$. While punishment or intent of punishment is to prevent the emergence of bad behavior and remind students not to do what should not djiwandono (2008: 144)

This research uses qualitative deskptive research method with focus of Reward and Punishment Implementation Implementation in Shaping Character of Early Age Anaka on Group B in RA An-Nawaa 3 Kota Cirebon. Data collection techniques use observation, interview and documentation. As for the primary data source is, principals and teachers of class B. and parents of secondary data source source is a reference from various books related rewards, punishment and discipline. To test the validity of the data using data triangulation. The result of this research is the implementation of reaward and punishment in forming the character of early childhood discipline specially in group B. In its application $R A$ An-Nawaa 3 gives a reward when the child performs a good action and gives punishment when the child performs an unlawful acts that violate Rules of conduct in the delivery of RA An-Nawaa 3 always consider the age and situation and conditions for the provision of rewards and punishment in accordance with the needs. The form of reward given to his child is verbal and non verbal rewards while for his punishment teachers only provide verbal punishment.
\end{abstract}

Keywords: Reward, Punishment, Discipline

Implementasi Pemberian Reward dan Punishment dalam Mila Sabartiningsih, Jajang Aisyul M Membentuk Karakter Disiplin Anak Usia Dini 


\begin{abstract}
Abstrak
Disiplin merupakan salah satu kebutuhan dasar anak dalam rangka pembentukan dan pengembangan wataknya secara sehat. Tujuannya ialah agar anak dapat secara kreatif dan dinamis dalam mengembangkan hidupnya dikemudian hari. Kasih sayang tanpa disiplin mengakibatkan munculnya rasa sentiment dan ketidak pedulian, sebaliknya disiplin tanpa kasih sayang merupakan tondakan kejam. Orangtua dan guru selalu memikirkan cara yang tepat dalam menerapkan disiplin disiplin bagi anak sejak balita hingga masa anak-anak dan sampai usa remaja. Penelitian ini bertujuan untuk memperoleh data mengenai Implementasi Pemberian Reward Dan Punishment Dalam Membentuk Karakter Disiplin Anak Usia Dini Pada Kelompok B di RA An-Nawaa 3 Kota Cirebon. dalam rangka dalam rangka mendisiplinkan anak usia dini khususnya pada kelompok B. guru menggunakan beberapa strategi diantanya pemberian reward dan punishment . Reward artinya hadiah, penghrgaan yang dijadikan sebagi alat pendidikan dan diberikan ketika seseorang anak melakukan suatu yang baik atau telah berhasil mencapai sebuah tahap perkembangan tertentu. Kopri $(2015 ; 289)$. Sedangkan punishment atau maksud dari hukuman adalah mencegah timbulnya tingkah laku yang tidak baik dan mengingatkan siswa untuk tidak melakukan apa yang tidak boleh djiwandono $(2008 ; 144)$. Jenis penelitian ini menggunakan metode penelitian deskptif kualitatif dengan fokus penelitian Implementasi Pemberian Reward dan Punishment dalam Membentuk Karakter Anaka Usia Dini pada Kelompok B di RA An-Nawaa 3 Kota Cirebon. Teknik pengumpulan data menggunakan observasi, wawancara dan dokumentasi. Adapun yang menjadi sumber data primer adalah, kepala sekolah dan guru kelas B. dan orangtua murid sumber data sekundernya adalah referensi dari berbagai buku terkait reward, punishment dan kedisiplinan . Untuk uji keabsahan data menggunakan triangulasi data. Hasil dari penelitian ini adalah Implementasi pemberian reaward dan punishment dalam membentuk karakter disiplin anak usia dini khususnya pada kelompok B. dalam penerapannya RA An-Nawaa 3 memberikan sebuah reward ketika anak melakukan suatu tindakan baik dan memberikan punishment ketika anak melakukan suatu tindakan kurang baik yang melanggar peraturan tata tertib dalam penerpan pemberiannya RA An-Nawaa 3 selalu mempertimbangkan usia serta situasi dan kondisi agar pemberian reward dan punishment sesuai dengan kebutuhan. Adapun bentuk reward yang diberikan kepada anaknya yaitu reward verbal dan non verbal sedangkan untuk punishment nya guru hanya memberikan punishment verbal.
\end{abstract}

Kata Kunci : Reward, Punishment , Kedisiplinan

\title{
PENDAHULUAN
}

Disiplin merupakan salah satu kebutuhan dasar anak dalam rangka pembentukan dan pengembangan wataknya secara sehat. Tujuannya ialah agar anak dapat secara kreatif dan dinamis dalam mengembangkan hidupnya dikemudian hari.

Wiyani (2014: 109) berpendapat bahwa mendisiplinkan para remaja merupakan hal besar yang dapat membantu dalam membimbingnya menuju tahap kedewasaan yang lebih baik. Namun bukan hanya bagi remaja saja, karakter disiplin juga sangat penting dimiliki bagi anak usia dini. Oleh karena itu orang tua perlu membentuk karakter disiplin pada anak sedini mungkin walaupun ada yang berasumsi bahwa pada anak usia dini masih belum mempunyai tanggung jawab yang besar dan kedisiplinan bukan merupakan hal yang penting. 
Tujuan disiplin adalah mengerahkan anak agar belajar mengeni hal-hal baik yang merupakan persiapan bagi masa dewasanya, dimana anak sangat bergantung kepada disiplin diri dan pembentukan perilaku sedemikian rupa hingga ia akan sesuai dengan peran-peran yang ditetapkan kelompok budaya tertentu. Tempat individu itu diidentifikasikan.

Disiplin negatif memperbesar kematangan individu, sedangkan disiplin positif akan menumbuhkan kematangan. Fungsi pokok disiplin ialah mengajarkan anak menerima pengekangan yang diperlukan dan membantu mengarahkan energi anak kedalam jalur yang berguna dan diterima secara sosial. Oleh sebab itu disiplin positif akan membawa hasil yang lebih baik dari pada disiplin negatif. Berdasarkan latarbelakang diata maka peneliti tertarik untuk menliti konsisi kedisiplinan yang ada di RA An-Nawaa 3, bentuk reward dan punishment yang diberikan serta implementasi dalam pemeberian reward dan punishment pada kelompok B.

Meurut Sudarna (2014: 61), Disiplin berasal dari bahasa inggris discipline (kata benda; kata kerja disciplined, diclipining; latin disciplina. Instruction), berarti "training to act anaccordance with rules," melatih (atau pelatihan) seseorang (bisa juga binatang) untuk bertindak (berperilaku) sesuai aturan. Menurutnya anak didisiplinkan (dilatih) supaya berperilaku sesuai aturan (Menurut Fadlillah (2013: 192), disiplin ialah tindakan yang menunjukan perilaku tertib dan patuh pada berbagai ketentuan dan peraturan. Kedisiplianan dapat dilakukan dan diajarkan kepada anak di sekolah maupun di rumah dengan cara membuat semacam peraturan dan tata tertib yang wajib dipatuhi oleh setiap anak. Namun peraturan dibuat secara fleksibel, tetapi tegas dengan kata lain, peraturan menyesuaikan dengan kondisi perkembangan anak.

Dari beberap pengertian yang dikemukakan oleh para ahli, penulis menyimpulkan bahwa disiplin merupakan perasaan taat dan patuh terhadap nilai-nilai yang dipercaya termasuk melakukan pekerjaan tertentu yang menjadi tanggung jawabnya, sehingga individu dapat terbentuk oleh karakter disiplin diri melalui kedisiplinan yang diterapkan dan mampu membedakan hal-hal yang baik dan buruk dalam bermasyarakat.

Tujuan disiplin adalah membentuk perilaku sedemikian hingga akan sesuai dengan peran-peran yang ditetpkan kelompok budaya atau tempat individu itu diidentifikasikan. Hurlock (1978: 82).

Melalui pendisiplinan tanpa paksaan atau dengan kesadaran akan kegunaan manfaat disiplin menjadi dua yaitu, pertama tujuan jangka pendek dari disiplin ialah membuat anak-anak terlatih dan terkontrol, dengan mengjarkan mereka bentuk bentuk tingkahlaku yang pantas dan Implementasi Pemberian Reward dan Punishment dalam Mila Sabartiningsih, Jajang Aisyul M Membentuk Karakter Disiplin Anak Usia Dini 
tidak pantas atau yang masih asing bagi mereka. Sedangkan tujuan jangka panjang disiplin ialah perkembangan pengendalian diri sendiri (selfcontrol dan selfdirection) yaitu dalam hal mana anak-anak dapat mengarahkan diri sendiri tanpa pengaruh dan pengendalian dari luar. Hurlock, Sujiono (2005: 32).

Hurlock (1999:84) menyatakan lima unsur pokok mendisiplinkan anak, yaitu:

a) Peraturan, b) Kebiasaan-kebiasaan, c) Hukuman, d) Penghargaan

Menurut Direktorat Jendral departemen Agama Proses terjadinya disiplin dapat digambarkan sebagai berikut. Seorang anak setelah menerima perlakuan untuk disiplin. Disebut pembiasaan (dengan dua cara), akan manyadari (kesadaran) suatu tingkah laku baru yang ia masukkan dalam persepsi pribadinya. Setelah ia mencoba kesadaran baru dalam bentuk percobaan tingkah laku. Akibat dari tindakan ini akan dijadikan sebagai persepsi permanennya.

Bentuk dari persepsi permanen inilah yang disebut disiplin. Dengan pengaruh yang bersifat jangka panjang atau jangka pendek. Disiplin dapat ditempuh melalui dua cara yaitu melalui pembiasaan dangan peneguhan dan pembiasaan dengan hukuman. Pembiasaan dengan hukuman tanpa peneguhan biasanya memberikan pengaruh jangka pendek. Lain halnya dengan pembiasaan disertai peneguhan setelah hukuman, dan pembiasaan dengan peneguhan karena berperilaku baik. Pembiasaan dengan peneguhan adalah seorang anak berperilaku baik dan diberikan imbalan berupa pujian atau sebagainya atas perilaku tersebut.

Karakteristik Perkembangan Disiplin Anak

Salah satu konsep penting yang harus ditanamkan pada masa kanak-kanak adalah harus menyesuaikan melalui proses perkembangan sesuai usia dirinya. Disiplin tidak tertanam begitu saja, akan tetapi perkembangan disiplin sesuai karakteristik perkembangan anak dari usia 0-8 tahun, adapun karakteristik perkembangan disiplin pada asa kanak-kanak (3-6 tahun) fenomena yang tampak diantaranya, melalui cerita fiktif maupun sebenarnya, konsekwensi yang harus diterima apabila berbuat salah atau benar, disiplin dalam kegiatan sehari-hari, anak mulaai patuh terhadap tuntunan orangtua dan lingkungan sosialnya, dapat merapikan kembali mainan yang habis dipakai, mencuci tangan sebelum dan sesudah makan.

Indikator Kedisiplinan

Berdasarkan standar isi tingkat pencapaian perkembangan anak usia dini dalam peraturan menteri pendidikan dan kebudayaan republik Indonesia nomor 137 tahun 2014 dalam lingkup perkembangan sosial emosional pada perkembangan anak usia 5-6 tahun. 
Anak tahu akan haknya, Mentaati aturan kelas (kegiatan, aturan), Mengatur diri sendiri, Bertanggungjawab atas perilakunya unruk kebaikan diri sendiri, Mengenal tatakrama dan sopan santun sesuai dengan nilai budaya setempat.

Menurut Kosim Reward artinya ganjaran, hadiah, penghargaan atau imbalan. Reward sebagai alat pendidikan diberikan ketika seorang anak melakukan sesuatu yang baik, atau telah berhasil mencapai sebuah tahap perkembangan tertentu, atau tercapainya sebuah target. Dalam konsep pendidikan reward merupakan salah satu alat untuk peningkatan motivasi para pserta didik. Metode ini bisa mengasosiasikan perbuatan dan kelakuan seseorang dengan perasaan bahagia, senang dan biasanya akan membuat mereka melakukan suatu perbuatan yang baik secara berulang ulang selain motivasi. Kompri (2015: 289).

Meurut Maslow penghargaan adalah salah satu dari kebutuhan pokok yang mendorong seseorang untuk mengaktualisasikan dirinya. Sedangkan menurut Goodman pemberian penghargaan harus didasarkan kepada prinsip bahwa penghargaan itu akan memberi motivasi kepada anak untuk meningkatkan dan untuk memperkuat anak untuk menghindarkan tindakantindakan yang tidak diinginkan oleh masyarakat. Dalam BukuUno yang berjudul Teori Motivasi dan Pengukurannya dalam Pendidikan (2013: 38).

Jadi dapat disimpulakan bahwa reward adalah suatu cara yang dilakukan oleh seseorang untuk memberikan suatu penghargaan kepada seseorang karena sudah mengerjakan suatu hal yang benar, sehingga seseorang itu bisa semangat lagi dalam mengerjakan tugas tertentu dan lebih termotivasi dalam melakukan sesuatu hal yang lainnya serta lebih baik prosesnya sehingga seseorang tersebut mampu mencapai keberhasilan dari suatu hal yang ia kerjakan.

Fungsi penerapan reward

Menurut Hurlock (1978: 90) pemberian penghargaan mempunyai fungsi dan peranan fungsi penting dalam mengembangkan perilaku anak sesuai dengan cara yang disetujui masyarakat, diantaranya:Penghargaan mempunyai nilai mendidik, Penghargaan berfungsi sebagai moivasi, Penghargaan berfungsi memperkuat perilaku yang disetujui secara sosial Tujuan reward

Tujuan yang harus dicapai dalam pemberian reward adalah untuk lebih mengembangkan motivasi yang bersifat instrinsik dari motivasi ekstrinsik, dalam artian siswa melakukan suatu perbuatan, maka perbuatan itu timbul dari kesadaran siawa itu sendiri. Dan dengan adanya reward diharapkan dapat membangun suatu hubungan yang positif antar siswa, karena reward itu adalah bagian dari pada rasa cinta kasih sayang seorang guru kepada siswa. 
Komponen-komponen reward

Menurut Usman (1992: 73) menyebutkan bahwa keterampilan dasar penerapan reward terdiri atas beberapa komponen, diantarnya:

a. Reward Verbal (Pujian): Kata-kata bagus: ya benar, tepat, bagus sekali, dan lain-lain, Kalimat: pekerjaan anda baik sekali, saya senang dengan hasil pekerjaan anda

b. Reward Non Verbal: Reward berupa gerak mimik dan badan antra lain : senyuman, acungan jari (jempol), tepuk tangan, dan lain-lain

Punishment hukman menurut bahasa berasal dari bahsa inggris yaitu dari kata Punishment yang berarti law (hukuman) atau siksaan. Sedangkan menuerut istilah ada beberapa pendapat yang dikemukakan oleh para ahli pendidikan tentang Punishment (hukuman). Menurut Purwanto (2005:186) maksud dari hukuman (Punishment) ialah penderitaan yang diberikan atau ditimbulkan dengan sengaja oleh seseorang (orang tua, guru, dan sejajarnya) sesudah terjadi suatu pelanggaran, kejahatan, atau kesalahan, adapun menurut Menurut Djiwandono (2008:144) maksud dari hukuman adalah mencegah timbulnya tingkah laku yang tidak baik dan mengingatkan siswa untuk tidak melakukan apa yang tidak boleh. Punishment adalah penderitaan yang diberikan atau ditimbulkan dengan sengaja oleh pendidik setelah siswa melakukan pelanggarana atau kesalahan. Hamruni $(2008 ; 120)$.

Dari beberapa pengetian di atas penulis menyimpulkan bahwa yang di maksud dengan hukuman (Punishment) adalah tindakan yang diberikan oleh pendidik terhadap anak didik yang telah melakukan kesalahan, dengan tujuan agar anak didik tidak akan mengulanginya lagi dan akan memperbaiki kesalahan yang telah diperbuat.

Suatu hukuman itu pantas diberikan kepada sisiwa bilaman nestapa yang ditimbulkan itu mempunyai nilai positif dan pedagogis. Adapun tujuan Punishment (hukuman) itu sendiri ialah: Hukuman didakan untuk membasmi kejahatan atau untuk meniadakan kejahatan., Hukuman diadakan untuk melindungi masyarakat dari perbuatan yang tidak wajar, Hukuman diadakan untuk menakut-nakuti si pelanggar, agar tidak meninggalkan perbuatan yang tidak wajar., Hukuman harus diadakan untuk segala pelanggaran.

Tujuan pemberian hadiah sama dengan tujuan penerapan pemberian hukuman yaitu membengkitkan perasaan dan tanggung jawab atas perbuatan yang dilakukannya. M.Arifin (2003: 22).

Adapun manfaat dalam pemberian Punishment (hukaman) yaitu untuk memotivasi anak melakukan kebaikan dan meningkatkan prestasi belajar mereka. Namun perlu diingat bahwa Implementasi Pemberian Reward dan Punishment dalam Mila Sabartiningsih, Jajang Aisyul M Membentuk Karakter Disiplin Anak Usia Dini dan Durtam 
tujuan tersebut akan sukses bila pemberian Punishment itu dilakukan secara bijak,tepat dan tidak berlebihan. Untuk pemberian Punishment sendiri hendaknya diberikan dengan cara cara yang dapat memperbaiki dan mendidik ke arah yang lebih baik.

Menurut Ibnu Sina dalam buku perbandingan pendidikan islam karya Ali Al-jumbulati menatakan bahwa suatu kewajiban pertama ialah mendidik anak dengan sopan santun, membiasakannya dengan perbuatan yang terpuji sejak mulai disapih, sebelum kebiasaan jelek mempengaruhinya. Penerapan pemberian Punishment(hukuman) terdiri dari beberapa komponen, diantaranya:

a. Punishment Verbal

Jika terpaksa mendidik anak dengan hukuman, sebaiknya berikan Punishment (hukuman) verbal dulu yaitu orang tua atau guru memberikan peringatan dan ancaman terlebih dahulu jangan menindak anak dengan kekerasan tetapi dengan kehalusan hati, lalu diberi motivasi, persuasi kepada perbuatan baik, dengan muka masam, atau kadang-kadang dipuji, didorong keberaniannya untuk berbuat baik. Perbuatan demikian merupakan perilaku yang mendahului tindakan khusus.

\section{b. Punishment Non Verbal}

Tetapi jika terpaksa harus memberikan Punishment (hukuman non verbal) cukuplah pukulan sekali yang menimbulkan rasa sakit, karena pukulan yang cukup banyak anak merasa ringan, dan memandang hukuman itu sebagai suatu yang remeh. Menghukum dengan pukulan dilakukan setelah melakukan peringatan keras dan menjadikan sebagai alat penolong untuk menimbulkan pengaruh positif dalam jiwa anak.

Menurut teori behavioristik, belajar adalah perubahan tingkah laku sebagai akibat adanya interaksi antara stimulus (rangsangan) dan respon (tanggapan). Menurut teori ini hal yang paling penting adalah input (masukan) yang berupa stimulus dan output (keluaran) yang berupa respon. Berbeda dengan teori behavioristik, teori kognitif lebih mementingkan proses belajar dari pada hasil belajarnya. Teori ini mengatakan bahwa belajar tidak sekedar melibatkan hubungan antara stimulus dan respon, melainkan tingkah laku seseorang ditentukan oleh persepsi serta pemahamannya tentang situasi yang berhubungan dengan tujuan belajarnya. Teori kognitif juga menekankan bahwa bagian-bagian dari suatu situasi saling berhubungan dengan seluruh konteks situasi tersebut. 
Teori sosialististik berpangkal pada dalil bahwa tingkah laku manusia sebagian besar adalah hasil pemerolehan, dan bahwa prinsip-prinsip belajar adalah cukup untuk menjelaskan bagaimana tingkah laku berkembang dan menetap.

Sosial adalah interaksi atau hubungan yang dilakukan dengan orang banyak yang ditemukannya disekelilingnya dalam menjalankan kehidupan individunya sehari-hari. Sosial membantu tiap anak untuk merasa diterima didalam kelompok, membantu anak belajar berkomunikasi dan bergaul dengan orang lain, mendorong empati dan saling menghargai terhadap anak-anak maupun orang dewasa. Yang akan dibahas kali ini adalah lingkungan pembelajaran yang berasal dari teman sebaya, karena melalui teman sebaya, mendorong anak untuk meningkatkan kemampuannya, sekaligus memberikan dukungan sosial kepada anak berupa perhatian, persetujuan, penghargaan sekaligus hukuman, model perilaku yang akan ditiru oleh anak tersebut. (Eti Nurhayati, 2011:37)

\section{METODOLOGI}

Metode penelitian merupakan usaha untuk menemukan, mengembangkan, dan mnguji suatu kebenaran pengetahuan dengan menggunakan cara-cara ilmiah. Sugiyono (2013: 6)

Tempat yang menjadi sasaran dalam penelitian ini adalah RA An-Nawaa 3 yang berlokasi di Jl. Sekar kemuning kelurahan karya mulya kecamatan kesambi kota Cirebon propinsi Jawa Barat. Pemilihan sarana lokai ini mempertimbangkan berbagai kelebihan yang dimiliki oleh RA An-Nawaa 3 yang diantaranya adalah lokasi sekolah yang cukup strategis, manegemen pembelajaran yang cukup baik, serta strategi pembelajaran yang cukup menarik.

Jenis Penelitian yang dipakai dalam penelitian ini adalah penelitian kualitatif deskriptif. Penelitian kualitatif deskriptif ialah penelitian yang berusaha menggambarkan atau menguraikan "apa adanya" tentang suatu variabel, gejala atau keadaan Arikunto (1993:310). Pendekatan kualitatif diambil karena dalam penelitian ini peneliti menelaah tentang fenomena sosial mengenai kedisiplinan anak usia dini dalam suasana yang berlangsung secara wajar atau alamia

Data yang diperoleh untuk kepentingan penelitian didapat dari dua jenis sumber data, yaitu :

a) Sumber data primer atau data tangan pertama yaitu data yang diperoleh langsung dari subjek penelitian dengan mengenakan alat pengukuran atau alat pengambilan data langsung pada subjek. Sebagai subjek langsung, pada subjek sebagai sumber informasi yang dicari. Adapun yag dijadikan sumber data primer dalam penelitian ini adalah kepala sekolah, guru

kelas, dan waali murid kelas B RA An-Nawaa 3 kota Cirebon. b) Sumber data sekunder, Implementasi Pemberian Reward dan Punishment dalam Mila Sabartiningsih, Jajang Aisyul M 
atau data tangan kedua yaitu data yang diperoleh lewat pihak lain, tidak langsung diperoleh oleh peneliti dari subjek penelitiannya. (saifuddin Azwar, 2012:91) misalnya : masyarakat lingkungan sekolah, orangtua, buku pustaka, artikel, dan dokumentasi foto.

Instrument penelitian adalah alat-alat yang digunakan dalam penelitian untuk memperoleh data yang diharapkan. Adapun alat-alat tersebut meliputi :Lembar observasi. Pedoman wawancara, Handphone, Camera digital, dan alat tulis lainnya.

pengumpulan data dalam penelitian ini dilakukan dengan mencari sumber-sumber literature (referensi) berupa buku-buku, surat kabar dan artikel online yang sesuai dan terkait dengan pokok bahasan yang diangkat. Data atau informasi yang menjadi bahan baku penelitian, untuk diolah merupakan data yang berwujud data primer dan sekunder.

Analisis data adalah proses mengorganisasi dan mengurutkan antara pola kategori, dan satuan uraian dasar sehingga dapat ditemukan dan dapat diluruskan hipotesis kerja seperti yang disarankan oleh data. Moleong (2000:103).

1) Pengumpulan data, 2) Reduksi data, 3) Penyajian data, 4) Penarikan kesimpulan data

Penelitian kualitatif menghadapi persoalan penting mengenai pengujian keabsahan hasil penelitian. Banyak hasil penelitian kualitatif yng diragukan kebenarannya karena beberapa hal. Diantaranya; Pertama subjektivitas peneliti merupakan hal yang dominan dalam penelitian kualitaif Kedua, alat peneliti yang diandalkan adalah wawancara dan observasi mengandung banyak kelemahan ketika dilakukan secara terbuka apalagi tanpa control. Ketiga, sumber data kualitatif yang kurang kredibell akan mempengaruhi hasil akurasi penelitian.

\section{HASIL PENELITIAN DAN PEMBAHASAN}

Berdasarkan hasil observasi dan wawanncara yang dilakukan peneliti bahwa RA AnNawaa 3 merupakan salah satu lembaga pendidikan RA yang mempunyai ciri khas tersendiri dalam mengatur strategi untuk anak didiknya, selain mendidik dengan hati dan kesabaran guruguu RA An-Nawaa 3 juga selalu menghargai prilaku baik anaak didiknya dengan memberikan suatu reward (hadiah), bukan hanya prilaku baik yang diperhatikan melainkan sebaliknya ketika anak didiknya melakukan prilaku yang kurang baik guru pun selalu mengingatkan anak didiknya untuk tidak melakukan kesalahan yang sama namun tidak hanya diingatkan biasanya gurupun memberikan punishment (hukuman) yang sesuai, dengan kesalahannya, karakternya maupun usianya.

Ibu SN berpendapat bahwa "biasanya bentuk reward yang saya kasih kepada murid khusunya kelas B1, saya kasih sebuah "bintang", yang dikumpulkan di papan prestasi anak, Implementasi Pemberian Reward dan Punishment dalam Mila Sabartiningsih, Jajang Aisyul M Membentuk Karakter Disiplin Anak Usia Dini 
selain berbentuk "bintang" juga saya kasih "acungan "jempol”, sentuhan dan ucapan-ucapan seperti "anak hebat" "kamu OK" "anak ganteng" "anak cantik". Engga Cuma reward saja yang saya kasih ke anak tetapi punishment pun saya kasih ketika anak berbuat kesalahan punishment yang saya kasih biasanya hanya teguran sebagai pengingat agar tidak mengulanginya lagi, serta perintah utuk beristighfar, anak diperintahkan untuk beristighfar atas kesalahannya dan mengancam akan menghapus beberapa" bintang" yang ada di papan prestasinya." (catatan wawancara 03 april 2017).

Ibu Y sebagai wali kelas B2 juga diwawancarai mengenai kondisi kedisiplinan RA AnNawaa 3 beliau mengatakan bahwa; "dalam mendisiplinkan anak usia dini tidaklah mudah, oleh karena itu kami selaku guru disini terus berusaha agar anak mau mendisiplinkan dirinya sendiri, dengan berbagai macam cara seperti, sapaan-sapaan yang halus, sentuhan serta selalu mengingatkan, dengan adanya tata tertib yang ada kami mencoba melatih kedisiplinan anak, ada beberapa anak B2 yang sering terlambat 1 sampai 3 orang saja, namun mengingat kelas B2 terdapat 20 murid. Alhamdulillah hanya sebagian kecilnya saja yang masih harus mendapat bimbingan yang lebih dalam melatih kedisiplinannya. Dengan adanya bimbingan secara tidak langsung guru merangkul anak dalam mematuhi tata tertib yang ada di sekolah namun dalam melatih kedisiplinan pada anak diperlukan waktu yang cukup lama oleh karena itu sebagai guru RA harus memiliki kesabaran yang ekstra dalam menghdapi anak didiknya tetapi jika dalam bibingannya berhasil kita sebagai guru merasa bangga sehingga anak terbiasa menjalankan tata tertib aturan yang ada, dengan terbiasanya menjalankan aturan maka dengan sendirinya karakter disiplin anak akan terbentuk dengan terbentuknya karakter maka ketika di lingkungan masyarakat anak akan mampu mngikuti aturan yang ada di lingkungan tersebut tanpa harus mebentuk lagi Karena karakternya sudah terbentuk sejak dini”(catatan wawancara 3, 10 April 2017).

Berdasarkan hasil observasi dan wawancara yang dilakukan peneliti, pada para wali kelas B yang ada di RA An-Nawaa 3, bahwa penerapan reward "bintang” yang diterapkan pada kelompok B dilakukan ketika anak mampu menyelaesaikan pekerjaannya misalkan, menyelesaikan tugasnnya, menghabiskan makanannnya ketika makan bersama, membantu/menolong temannya ketika sedang kesusahan Bukan hanya reward "bintang" saja guru pun terkadang member teward " acungan jempol” ketika anak membaca doa dengan baik, membaca surat - surat pendek dengan suara lantang dan benar. 
Namun dalam penerapan punishment biasanya guru menerapkannya menggunakan strategi yang menyesuaikan situasi, kondisi serta karakter anak. Misalkan; ketika anak mengganggu temannya hingga menangis, lalu kemudian guru memberikan punishment dengan menyuruhnya meminta maaf, nakan tetapi ketika si anak masih tidak mau meminta maaf, maka si anak harus beristighfar agar tidak mengulagi kesalahan yang sama. Tidak hanya itu gurupun melakukan tindakan untuk menghapus "bintang" yang ada di papan prestasinya.

Orangtua pun berpendapat bahwa "sistem penerapan reward dan punishment disekolah sangat bagus dan sangat setuju karena berdampak sangat baik pada saat anak berada di rumah, bahkan ketika di rumah saya harus mengikuti cara gurunya di sekolah, yaitu dengan cara menrapkan peemberian reward dan punishment yang diberikan guru" (catatan wawancara 4, 11 April 2017).

Senada dengan Sudarna (2014: 61), "training to act anaccordance with rules," melatih (atau pelatihan) seseorang (bisa juga binatang) untuk bertindak (berperilaku) sesuai aturan. Menurutnya anak didisiplinkan (dilatih) supaya berperilaku sesuai aturan (rule) yang berlaku dalam masyarakat. Mengingat usia nya yang masih tergolong golden age, melatih anak usia dini terbilang mudah karena ia akan mudah mengingat dan meniru, namun saat proses melatih terkadang anak juga memiliki karakter yang mudah bosan oleh karena itu sebagai guru RA harus lebih kreatif dan berinovasi dengan strategi yang digunakannya agar anak tidak mudah bosan.

Mengingat teori yang dikemukakan diatas maka dalam membentuk karakter disiplin anak tidaklah mudah. Seorang guruharus memiliki berbagai macam strategi dalam mendisiplinkan anak usi dini. Dengan membimbing dan melatih adalah salah satu cara yang digunakan guruguru RA An-Nawaa 3 dalam membentuk karakter disiplin. Dengan adanya bimbingan secara tidak langsung anak berlatih untuk mematuhi tata tertib yang berlaku disekolah dan mendisiplinkan dirinya sendiri.

Ibu HT sebagai wali kelas B3 juga diwawancarai mengenai kondisi kedisiplinan anak di RA An-Nawaa 3, beliau berpendapat bawhwa; "kondisi kedisiplinan di sekolah alhamdulillah sudah baik, walaupun pada awalnya kami sebagai guru harus mendidik dan melatih anak agar terbiasa dengan tata tertib aturan yang ada, saya sendiri melatih anak-anak dengan berbeda cara pada setiap anak, karena setiap anak pun memiliki karakter yang berbeda walaupun pada hakikatnya usia dini adalah usia golden age, disamping karakternya yanag berbeda, khususnya kelas B3 memiliki rentan usia yang berbeda-beda, ada yang baru usia 5tahun, 5 tahun 6bulan, 
hingga 6 tahun, oleh karena itu berbeda cara ddalam mengatai pada setiap anak selain menggunakan strategi kamipun tidak lepas dari kerjasama orangtua di rumah, ada beberapa anak yang sering terlambat datang di sekolah namun hanya sebagian kecil saja mengingat kelas B3 terdapt usia yang berbeda-beda maka saya pun menanganinya dengan cara yang berbeda pula, akan tetapi komunikasi dan kerjasama dengan orangtua pun selalu saya lakukan. Selama ini hanya 1-3 orang saja yang kadang-kadang terlambat datang ke sekolah. Tak lupa juga saya menanyaka alasan dari keterlambatan si anak, dan biasanya pemberian dan punishment selalu di terapkan karena itu adalah strategi andalan kami dn anak-anak pun mau menerima ketika strategi tersebut diterapkan akan tetapi sebelum pemberian reward dan punishment biasanya saya membuat perjanjian terlebih dahulu dengan anak, apabila si anak menepati janjinya maka anak akan diberikann reward namun apabila anak melanggar janjinya maka anak akan mendapatkan punishmen "(catatan wawancara 3, 11 April 2017).

Kelas B3 merupakan salah satu kelas yang istimewa karena di dalam kelas B3 terdapat 17 murid yang memiliki beragam usia. Untuk itu guru harus mampu menghadapi berbagai macam sifat dan karakter anak karena mengingat usianya yang berbeda-beda. Usia yang dimiliki anak-anak B3 sendiri mulai dri 5 tahun, 5tahun 6 bulan serta ada juga yag 6 tahun. Dengan usia tersebut kemandirian anakpunberbeda akan tetapi ibu HT selalu mempunyai cara dlam melatih kemandirian anak terutama dalam melayani diri sendiri. Tidak hanya melatih kemandirian anak, ibu HT pun mampu melatih kedisiplinan anak dan mengajarkan anak didiknya untuk mau memetuhi dan menjalankan tata tertib yang ada di sekolah. Salah satu cara yang dilakukan oleh ibu HT adalah dengan menerapkan pemberian reward dan dan punishment yang diberikan kepada anak. Namun sebelum memberikan rewrad dan punishment ibu HT melakukan perjanjian terlebih dahulu kepada anak, apabila si anak melanggar janjinya maka punishment lah yang akan di dpatkan namun apabila anak menepati janjinya maka reward lah yang akan didapatkan.

RA An-Nawaa 3 salah satu lembaga pendidikan Raudhatul Athfal yang memiliki berbagai macam strategi dalam menghadapi berbagai macam karakter anak. strategi merupakan hasil buah pikiran sesorang terhadap analisis objek disebabkan ada sesuatu yang ingin dicapai. Secara umum strategi mengandung makna rencana yang cermat mengenai kegiatan untuk mencapai sasaran khusus. Teori tersebut membuktikan bahwa seseorang yang memiliki pengalaman yang lebih banyak akan mampu menciptakan strategi atau cara dalam menghadapi objek demi tercapainya suatu tujuan. Terlihat juga pada RA An-Nawaa 3 yang memiliki tenaga 
pengajar yang sangat berpengalaman dalam mendidik anak dan sudah sering pula menghadapi anak usia dini yang memiliki berbagai macam karakter. Dengan berbekal pengalam dan ilmu yang mumpuni membuat guru-guru mudah dalam menghadapi anak-anak.

Namun ada salah satu cara/strategi yang menjadi ciri khas dari RA An-Nawaa 3 dalam menghadapi tingkah laku anak tertutama dalam mendisiplinkan anak. Cara tersebut yaitu dengan memberikan reward sebagai penghargaan kepada anak ketika anak berbuat baik dan punishment sebagai hukuman. Teguran atau peringatan ketika anak berbuat yang kurang disukai oleh masyarakat sekolah. Salah satunya adalah melanggar tata tertib sekolah, dengan adanya reward dan punishment yang diberikan kepada anak akan termotivasi untuk terus melakukan hal yang baik bahkan meningkatkan perbuatan baiknya karena dengan diberikannya rewrad anak akan merasa dihargai disetiap tindakannya. Namun sebaliknya ketika anak-anak mendapatkan punishment anak akan termotivasi untuk melakukan hal yang baik dan meninggalkan hal yang uruk karena dengan diberikannya punishment anak akan merasa bahwa perbuatan yang dilakukannyaakan membahayakan dirinya sendiri maupun oranglain.

Strategi pemberian reward dan punishment mampu mendisiplinkan anak terlihat bahwa jawaban wawancara diatas. Bahwasannya pada kelas B1 berjumlah 22 siswa dan anak yang kadang-kadang terlambat hanya 1 hingga 2 orang saja. Begitu pula dengan kelas B2 yang berjumlah hampir sama banyak dengan B1 yaitu terdapat 21 siswa dan anak yang sering terlambat hanya 1 hingga 2 orang saja namun berbeda dengan kelas B3 yang hanya berjumlah 17 siswa dan anak yang kadang-kadang terlambat 1 sampai 3 orang. Jika melihat keadaan tersebut maka jumlah seluruh kelas B di RA An-nawaa3 terdapat 60 siswa siwi dan anak yang kadangkadang terlambat kurang lebih berjumlah 8 orang dari seluruh kelas B yang berjumlah 60 murid.

Jika dipersentasikan hanya $12 \%$ siswa yang kadang-kadang datang terlambat dari dari $60 \%$ dari seluruh jumlah siswa kelas B. maka selebihnya terdapat 48\% siswa RA An-Nawaa 3 yang selalu datang tepat waktu sesuai peraturan tata tertib yang ada di sekolah. Akan tetapi siswa kadang-kadang terlambat ini mendapat bimbingan khusus dari guru bimbingan tersebut bertujuan agar anak yang kadang-kadang terlambat ini bisa meminimalisir keterlambatannya, tidak hanya dibimbing melainkan adanya komunikasi dan kerjasama antar orangtua dan guru dalam meminimalisirnya. 
Bentuk-Bentuk Reward dan Punishment Anak Usia Dini pada Kelompok B di RA AnNawaa 3

Berdasarkan hasil observasi dan wawancara yang dilakukan peneliti bahwa RA AnNawaa merupakan salah satu lembaga pendidikan RA yang mempunyai ciri khas tersendiri dalam mengatur strategi untuk anak didiknya, selain mendidik dengan hati dan kesabaran guruguu RA An-Nawaa 3 juga selalu menghargai prilaku baik anaak didiknya dengan memberikan suatu reward (hadiah), bukan hanya prilaku baik yang diperhatikan melainkan sebaliknya ketika anak didiknya melakukan prilaku yang kurang baik guru pun selalu mengingatkan anak didiknya untuk tidak melakukan kesalahan yang sama namun tidak hanya diingatkan biasanya gurupun memberikan punishment (hukuman) yang sesuai, dengan kesalahannya, karakternya maupun usianya.

Selain bentuk reward yang diberikan kepada murid-muridnya,untuk menyeimbangkannnya RA An-Nawaa 3 pun memberikan punishment yang berbentuk punishment verbal seperti; guru memberikan peringatan dan ancaman terlebih dahulu kepada anak ancaman yang diberikan biasanya guru akan mengingatkan untuk menghapus "bintang" yang ada di papan prestasinya, mengingatkan akan kesalahannya serta beristighfar atas kesalahannya dan berjanji untuk tidak mengulangi kesalahannya.mengingat bahwa punishment adalah tindakan yang diberikan oleh nendidik terhadap anak didik yang telah melakukan kesalahan, dengan tujuan agar anak didi. tidak akan mengulanginya lagi dan akan memperbaiki kesalahan yang telah diperbuat dan dengan catatan punishment yang diberikan adalah hukuman yang edukatif.

Di RA An-Nawaa bentuk reward yang diberikan adalah reward verbal (pujian) yang berupa kata-kata pujian seperti "anak sholeh, anak pintar, anak OK, hebat sekali, bagus sekli pekerjaannya dan sebagainya” serta reward non verbal yang berupa “ sentuhan, gerak mimik wajah, berupa symbol dan barang lainnya" tidak hanya reward, begitupun dengan punishment yang diberikan dalam bentuk verbal yaitu seperti ; "teguran, peringatan, dan perintah untuk melakukan suatu hal dan sebagainya" akn teteapi berbeda dengan bentuk reward, guru AnNawaa hanya memberikan bentuk punishment verbalnya saja, karena menurutnya jika kita ingin menghukum anak hukumlah terlebih dahulu dengan punishment verbal dan sedapat mungkin tidak memberikan punishment yang berbentuk non verbal (pukulan badan). jangan meninddak anak dengan kekerasan tetapi dengan kehalusan hati, lalu diberi motivasi, persuasi kepada 
perbuatan baik, dengan muka masam, atau kadang-kadang dipuji, didorong keberaniannya untuk berbuat baik. Perbuatan demikian merupakan perilaku yang mendahului tindakan khusus.

\section{Penerapan Pemberian Reward dan Punishment Anak Usia Dini pada Kelompok B Di RA} An-Nawaa 3

Berdasarkan hasil observasi dan wawancara yang dilakukan peneliti, pada para wali kelas B yang ada di RA An-Nawaa 3, bahwa penerapan reward "bintang" yang diterapkan pada kelompok B dilakukan ketika anak mampu menyelaesaikan pekerjaannya misalkan, menyelesaikan tugasnnya, menghabiskan makanannnya ketika makan bersama, membantu/menolong temannya ketika sedang kesusahan Bukan hanya reward "bintang" saja guru pun terkadang member teward " acungan jempol” ketika anak membaca doa dengan baik, membaca surat - surat pendek dengan suara lantang dan benar.

Namun dalam penerapan punishment biasanya guru menerapkannya menggunakan strategi yang menyesuaikan situasi, kondisi serta karakter anak. Misalkan; ketika anak mengganggu temannya hingga menangis, lalu kemudian guru memberikan punishment dengan menyuruhnya meminta maaf, nakan tetapi ketika si anak masih tidak mau meminta maaf, maka si anak harus beristighfar agar tidak mengulagi kesalahan yang sama. Tidak hanya itu gurupun melakukan tindakan untuk menghapus "bintang" yang ada di papan prestasinya.

Orangtua pun berpendapat bahwa "sistem penerapan reward dan punishment disekolah sangat bagus dan sangat setuju karena berdampak sangat baik pada saat anak berada di rumah, bahkan ketika di rumah saya harus mengikuti cara gurunya di sekolah, yaitu dengan cara menrapkan peemberian reward dan punishment yang diberikan guru" (catatan wawancara 4, 11 April 2017)

Terlihat bahwa Penerapan reward dan punishment yang di berikan kepada anak usia dini khususnya kelompok guru mempunyai strategi tersendiri tidak hanya itu gurupun selalu memperhatikan kondisi anak serta karakter anak karena setiap anak memiliki karakter yang berbeda, dengan strategi penerapan reward dan punishment guru pun sudah membuktikan bahwa setiap anak yang mendapatkan reward dan punishment akan berubah dengan strategi reward dan punishment juga guru bertujuan agar anak mampu mau berdisiplin dan mampu mentaati tat tertib yang ada di sekolah. Dampak positifnya adalah ketika anak sudah memiliki karakter disiplin maka anak juga akan mudah untuk beradaptasi dan mau menjalankan peraturan- 
peratuan yang berlaku di masyarakat ketika anak bersosialisasi dengan masyarkat yang ada di lingkungan sekitarnya.

Berdasarkan hasil penelitian dalam menerapkan pemberian reward dan punishment pada anak usia dini khususnya pada kelompok B ini selalu mempertimbangkan situasi dan kondisi, mempertimbangkan usia anak serta karakter anak, dengan mempertimbangkan hal-hal tersebut pemberian reward dan punishment menjadi imbang. Besar kecilnya perilaku baik yang dilakukan maka anak juga harus tetap mendapat reward sebagai tanda penghargaan dari perilaku yang dilakukannya begitupun sebaliknya besar kecilnya kesalahan yang dilakukan anak maka anak juga harus mendapatkan punishment/hukuman agar tidak mengulangi kesalahannya lagi. Untuk pemberian Punishment sendiri hendaknya diberikan dengan cara yang dapat memperbaiki dan mendidik ke arah yang lebih baik Dengan addanya penerapan pemberian reward yang dilakukan dilakukan di sekolah, orangtua pun ikut merasakan dampak positif dari hasil penerapan diterapkan.

Senada dengan pendapat Suharsimi Arikunto bahwa dalam memberikan reward hendaknya Penghargaan hendaknya disesuaikan dengan situasi ,keadaan dan sifat dari aspek yang menunjukan keistimewaan prestasi, penghargaan harus diberikan langsung sesudah perilaku yang dikehendakinya dilaksanakan, penghargaan harus diberikan sesuai kondisi orang yang menerimanya, penghargaan yang harus diterima anak hendaknya diberikan, penghargaan harus benar-benar berhubungan dengan prestasi yang dicapai, penghargaan soaial harus segera diberikan, jangan memberikan penghrgaan sebelum siswa berbuat.

\section{SIMPULAN}

Kondisi kedisiplinan di RA An-Nawaa 3 dilaksanankan dengan kategori cukup baik. Adanya peraturan tata tertib yang dibuat sekolah dan disetujui oleh komite sekolah, peraturan tersebut telah dijalnkan sesuai dengan peraturan tata tertib yang ada.

Bentuk reward dan punishment yang diberikan oleh guru An-Nwaa 3 kepada anak didiknya terbagi menjadi dua yaitu; reward verbal (pujian) seperti “anak sholeh", "anak pinter", “ok", "ya bagus" sedangkan yang non verbal seperti senyuman, acungan jempokl, sentuhan guru, symbol berbentuk "bintang", bertepuk tangan sebagai penghargaan begitupun dengan punishment yaitu punishment verbal seperti; guru memberikan peringatan terlebih dahulu, memberikan ekspresi dengan muka masam, kadang-kadang dipuji dan diberi motivasi untuk berani melakukan perbuatan baik. 
Proses pembentukan karakter disiplin pada anak usia dini khususnya pada kelompok B yang ada di RA An-Nawaa 3 ialah dengan cara menerapkan pemberiaan reward dan punishment . Cara penerapan yang dilakukan oleh guru An-Nawaa 3 yaitu dengan mempertimbangkan situasi dan kondisi anak, mmempertimbangkan jenis kelamin, usia serta tindakan yang diperbuat oleh anak. Dengan penerapan tersebut terbukti mampu melatih anak dalam berdisiplin terbukti pada saat observasi anak yang bertindak sesuai dengan tata terbib yang berlaku di sekolah akan diberikan reward sebagai penghargaan dan motivasi untuk terus melakukan bahakan meningkatkan tindakan baik yang dilakukan begitupun sebaliknya anak yang melakukan tindakan yang tidak sesuai dengan peraturan tata tertib sekolah akan diberikan punishment sebagai peringatan serta motivasi untuk melakukan tindakan yang sesuai aturan yang berlaku.

\section{DAFTAR PUSTAKA}

Aqib Zainal. (2011). Pendidikan Karakter.Bandung: CV Yrama Widya.

Direktorat Jenderal Kelembagaan Agama Islam. (1997). Pedoman Guru Pengembangan Agama Islam dan Disiplin Untuk Taman Kanak-Kanak. Jakarta: Departement Agama RI.

Dwi Lestari Ninin, Putra Nusa. (2013). Penelitian Kualitatif PAUD. Jakarta: PT Raja Gravindo.

Helmawati. (2015). Mengenal Dan Memahami PAUD. Bandung: PT Remaja Rosdakarya.

Hurlock Elizabeth B. (1978). Perkembangan Anak Jilid 2. Jakarta: Erlangga.

Kompri. (2015). Motivasi Pembelajaran Perspektif Guru dan Siswa. Bandung: PT Remaja Rosda Karya.

Latif, Mukhtar, dkk. (2013). Orientasi Baru Pendidikan Anak Usia Dini. Jakarta: Kencana Prenada Media Group.

Masnipal. (2013). Siap Menjadi Guru dan Pengelola PAUD Profesional. Jakarta: PT Elek Media Komputindo.

Munawara Budhy, Rachman. (2017). Pendidikan Karakter. The Asia Foundation.

Peraturan Menteri Pendidikan dan Kebudayaan Republik Indonesia Nomor 14 Tentang Sisdiknas Pendidikan Anak Usia Dini.

Sardiman. (1996). Interaksi dan Motivasi Belajar Mengajar Pedoman Guru dan Calon Guru. Jakarta: PT Raja Grafindo Persada.

Sudarna. (2014). PAUD Pendidikan Anak Usia Dini Berkarakter. Yogyakarta: Genius Publisher. 
Sugiyono. (2014). Metode Penelitian Pendidikan. Bandung: Alfabeta cv

Ulfah Maulidya, Suyadi. (2013). Konsep Dasar PAUD. Bandung: PT Remaja Rosdakarya.

Undang-undang Nomor 20 Tahun 2003 Tentang Sistem Pendidikan Nasional.

Ulwan, Abdullah Nashi. (2015). Pendidikan Anak Dalam Islam. Terjemah Arif Rahman Hakim Solo: Al-Andalus.

Uno. (2013). Teori Motivasi dan Pengukurannya. Jakarta: PT Raja Grafindo Persada. 